\title{
Regulation of translation factors elF4GI and 4E-BP1 during recovery of protein synthesis from inhibition by $\mathrm{p} 53$
}

\author{
C Constantinou $^{1}$ and MJ Clemens ${ }^{\star, 1}$
}

Activation of the tumour suppressor protein p53 rapidly inhibits protein synthesis. This is associated with dephosphorylation and cleavage of initiation factor elF4GI and the elF4E-binding protein 4E-BP1. When the activation of p53 is reversed within $16 \mathrm{~h}$ 4E-BP1 becomes rephosphorylated, the level of intact elF4GI slowly increases and protein synthesis gradually recovers. The recovery of protein synthesis is partially blocked by rapamycin and wortmannin but not by the protein kinase inhibitors PD98059 and CGP74514A. Both rapamycin and wortmannin, but not PD98059 or CGP74514A, delay the reappearance of elF4GI. In contrast, full-length 4E-BP1 rapidly becomes rephosphorylated and this process is partially inhibited by rapamycin, PD98059 and CGP74514A. Thus, activation of p53 results in the inhibition of distinct rapamycin- and wortmannin-sensitive pathways that target elF4GI, and rapamycin-sensitive and -insensitive pathways that target 4E-BP1. Following inactivation of p53 the gradual recovery is determined largely by the kinetics of restoration of elF4GI rather than by the rephosphorylation of full-length 4E-BP1. These findings suggest that the ability of cells to rephosphorylate 4E-BP1, resynthesise elF4GI and restore the rate of protein synthesis after inactivation of $\mathrm{p} 53$ is an important aspect of recovery following the relief of physiological stress.

Cell Death and Differentiation (2007) 14, 576-585. doi:10.1038/sj.cdd.4402045; published online 22 September 2006

Activation of the tumour suppressor protein $p 53$ causes a rapid inhibition of protein synthesis which precedes the induction of a cell cycle block and subsequent apoptosis. ${ }^{1-3}$ The inhibition of translation is accompanied by early dephosphorylation and cleavage of the eukaryotic initiation factor (elF)4E-binding protein 4E-BP1 as well as cleavage of polypeptide chain initiation factor elF4GI and dephosphorylation of this protein at Ser ${ }^{1108}$. 3 The cleaved products of 4E-BP1 and elF4GI, which are generated by a caspaseindependent mechanism, associate with elF4E and there is a correspondingly decreased extent of interaction of elF4E with full-length elF4GI. These changes are likely to play an important role in impairing the initiation of protein synthesis.

In this study, we have examined whether the inhibition of protein synthesis can be reversed when a temperaturesensitive form of p53 is inactivated, prior to the irreversible commitment to cell death, ${ }^{2}$ by return of the cells to the non-permissive temperature $\left(38^{\circ} \mathrm{C}\right)$. We have also investigated the requirement for various signalling pathways that are known to regulate protein synthesis and have analysed the integrity and state of phosphorylation of elF4GI and 4E-BP1 during the recovery phase. The results indicate a multifactorial mode of regulation of translation following the inactivation of p53 that is partially dependent on the activities of the protein kinase mammalian target of rapamycin (mTOR) and phosphatidylinositol-3-kinase (PI3k) but is independent of the protein kinases Mek1/2 and cdc2. Furthermore, our findings suggest that the rate of recovery of protein synthesis is limited by the kinetics of reappearance of elF4GI rather than by the extent of rephosphorylation of 4E-BP1 or the association of the latter with elF4E.

\begin{abstract}
Results
Characteristics of the recovery of protein synthesis following inactivation of $\mathbf{p 5 3}$. The activation of a temperature-sensitive form of $\mathrm{p} 53\left(\mathrm{Val}^{135}\right)$ inhibits protein synthesis in MEL cells. ${ }^{1}$ To determine if this inhibition is reversed when the cells are returned to the nonpermissive temperature for $\mathrm{p} 53$ activity $\left(38^{\circ} \mathrm{C}\right), \mathrm{Val}^{135}$ cells and a control cell line with a nonactivatable form of p53 (Pro ${ }^{190}$ ) were incubated at $32^{\circ} \mathrm{C}$ for $16 \mathrm{~h}$ and then returned to $38^{\circ} \mathrm{C}$ for various periods of time. Protein synthesis was then measured by $\left[{ }^{35} \mathrm{~S}\right]$ methionine incorporation. As shown in Figure 1a, although the control Pro ${ }^{190}$ cells showed a small inhibition of protein synthesis when incubated at $32^{\circ} \mathrm{C}$, upon return to $38^{\circ} \mathrm{C}$ they underwent a rapid recovery. In contrast, when the $\mathrm{Val}^{135}$ cells were incubated at $32^{\circ} \mathrm{C}$ a much greater inhibition of protein synthesis was observed (Figure 1b). Moreover, protein synthesis did not immediately recover upon return of these cells to $38^{\circ} \mathrm{C}$. After 8 and $24 \mathrm{~h}$ at $38^{\circ} \mathrm{C}$
\end{abstract}

\footnotetext{
${ }^{1}$ Translational Control Group, Centre for Molecular and Metabolic Signalling, Division of Basic Medical Sciences, St George's, University of London, Cranmer Terrace, London SW17 ORE, UK

${ }^{*}$ Corresponding author: MJ Clemens, Division of Basic Medical Sciences, St George's, University of London, Cranmer Terrace, London SW17 ORE, UK. Tel: + 44208725 5762; Fax: + 44208725 2992; E-mail: m.clemens@sgul.ac.uk

Keywords: $\mathrm{p53}$; polypeptide chain initiation factors; protein phosphorylation; protein synthesis; translational control

Abbreviations: 4E-BP, elF4E-binding protein; elF, eukaryotic initiation factor; Erk, extracellular-regulated kinase; MAPK, mitogen-activated protein kinase; Mek, MAPK kinase; MEL, murine erythroleukaemia; mTOR, mammalian target of rapamycin; PBS, phosphate-buffered saline; PI3k, phosphatidylinositol-3-kinase

Received 31.3.06; revised 19.7.06; accepted 11.8.06; Edited by M Oren; published online 22.9.06
} 
the rate had returned to only 49 and $77 \%$ of the control value respectively (Figure $1 \mathrm{~b}$ ).

We have previously reported that although the mechanism by which protein synthesis is inhibited in cells with active p53 involves the dephosphorylation of the mTOR substrate $4 \mathrm{E}$ $\mathrm{BP} 1$, this process is distinct from (and indeed additive with) the actions of the mTOR inhibitor rapamycin. ${ }^{3}$ It was therefore of interest to determine whether the recovery of protein synthesis is sensitive to rapamycin. When $\mathrm{Val}^{135}$ cells were incubated at $32^{\circ} \mathrm{C}$ for $16 \mathrm{~h}$ and then shifted back to the nonpermissive temperature in the presence or absence of $30 \mathrm{nM}$ rapamycin, the mTOR inhibitor partially prevented the recovery of protein synthesis (Figure 2a). In cells allowed to recover for up to $24 \mathrm{~h}$, rapamycin inhibited the restoration of protein synthesis by around $40-50 \%$. Even in cells returned to $38^{\circ} \mathrm{C}$ for $48 \mathrm{~h}$ rapamycin still inhibited the recovery by approximately $44 \%$ (data not shown). The inhibition of protein synthesis in recovering cells is in contrast to the very small inhibition of translation (ca. 11-20\%) that was observed when rapamycin was added to Pro ${ }^{190}$ cells or to $\mathrm{Val}^{135}$ cells that had been maintained at $38^{\circ} \mathrm{C}$ throughout (reference 3 and Figure $2 b$ ).

To examine the involvement of other signalling pathways in regulating the recovery of protein synthesis a number of other inhibitors were similarly added to the cells at the time of return to the nonpermissive temperature. As shown in Figure 2c, the PI3k inhibitor wortmannin also had a strong inhibitory effect on recovery. Like rapamycin, this agent was not strongly inhibitory towards cells prior to activation of p53 (Figure 2d). Nevertheless its presence resulted in a significant (ca. 50\%) impairment of recovery in cells returned to $38^{\circ} \mathrm{C}$ for $24 \mathrm{~h}$ (Figure 2c). It is well established that mTOR is regulated in a $\mathrm{PI} 3 \mathrm{k}$-dependent manner, via the action of the protein kinase Akt. ${ }^{4}$ It was therefore possible that wortmannin and rapamycin were both acting on the same pathway to cause impairment of mTOR activity. However, the addition of both inhibitors had a significant additive effect on protein synthesis. This was observed both in $\mathrm{Val}^{135}$ cells incubated at $32^{\circ} \mathrm{C}$ (where the inhibitors further increased the inhibition due to p53 activation - Figure $3 \mathrm{a}$ ) and in cells recovering after $24 \mathrm{~h}$ at $38^{\circ} \mathrm{C}$ (Figure $\left.3 \mathrm{~b}\right)$. These data suggest that at least two distinct pathways, sensitive to wortmannin and rapamycin respectively, are required for the reactivation of protein synthesis during the recovery from p53 inhibition.

The Mek1/2 kinase inhibitor PD98059 had only a small effect on the recovering cells (Figure 4a). This was not specific to p53-mediated regulation since the PD98059 was also somewhat inhibitory towards control cells at $38^{\circ} \mathrm{C}$ (Figure $4 \mathrm{~b}$ ). On the other hand, the p38 MAP kinase inhibitor SB203580 was very inhibitory to protein synthesis under all conditions (Figure $4 \mathrm{a}$ and $\mathrm{b}$ ). Both inhibitors were active against their respective target enzymes (Figure $4 \mathrm{c}$ ). Our results suggest that these inhibitors, especially SB203580, block pathways that are constitutively required for protein synthesis, independently of whether p53 is activated. In contrast, the mTOR and PI3k inhibitors block pathways that are only necessary for the recovery from p53-induced inhibition, and the compounds have very little effect when p53 is inactive. The cdc2 kinase inhibitor CGP74514A had very little effect on the recovery of protein synthesis from inhibition by $\mathrm{p} 53$, in the presence or
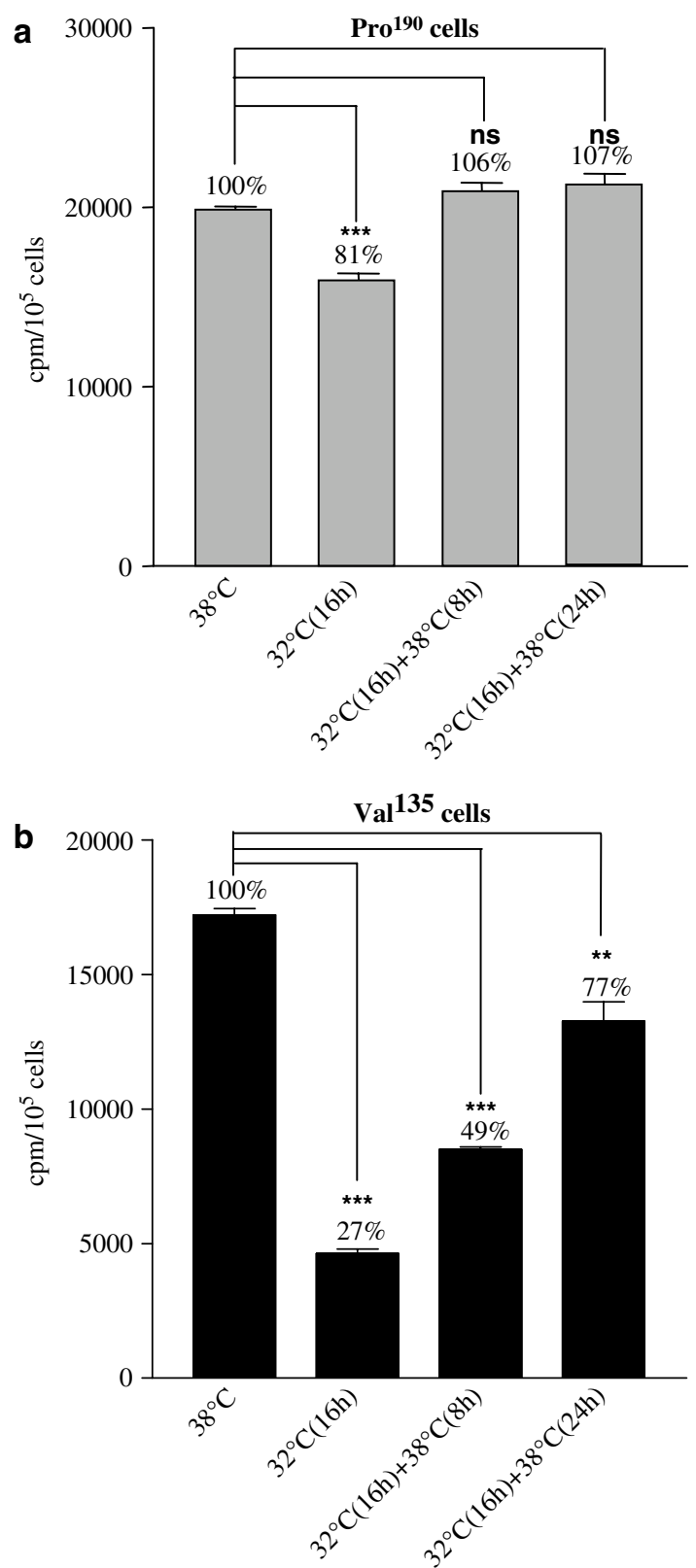

Figure 1 Inhibition of p53 activity results in slow recovery of the rate of protein synthesis. Pro ${ }^{190}$ cells (a) and Val ${ }^{135}$ cells (b) that had been cultured at $38^{\circ} \mathrm{C}$ were shifted to $32^{\circ} \mathrm{C}$ for $16 \mathrm{~h}$ and then shifted back to $38^{\circ} \mathrm{C}$ for the periods of time indicated. Rates of protein synthesis were measured during the last hour of incubation by pulse-labelling the cells with $\left[{ }^{35} \mathrm{~S}\right]$ methionine $(10 \mu \mathrm{C} / \mathrm{ml})$ as described in Materials and Methods. The data are expressed as radioactivity incorporated per $10^{5}$ cells \pm S.E.M. Relative rates of incorporation, expressed as \% of the control rate for each cell line (cells maintained at $38^{\circ} \mathrm{C}$ throughout), are shown above each bar. Statistical significances of differences between the values shown were calculated by paired t-test; ns indicates not significant $(P=0.05$ or greater), ${ }^{* *}$ indicates $P<0.001,{ }^{* * *}$ indicates $P<0.0001$

absence of rapamycin (Figure $4 d$ ). This compound was active under the conditions used since it caused the dephosphorylation of cdc2 at Thr $^{161}$ (Figure 4e). Thus, in spite of the ability of p53 to inhibit cdc2, ${ }^{5}$ activity of the latter kinase does not seem to be required for the restoration of translation. 
a

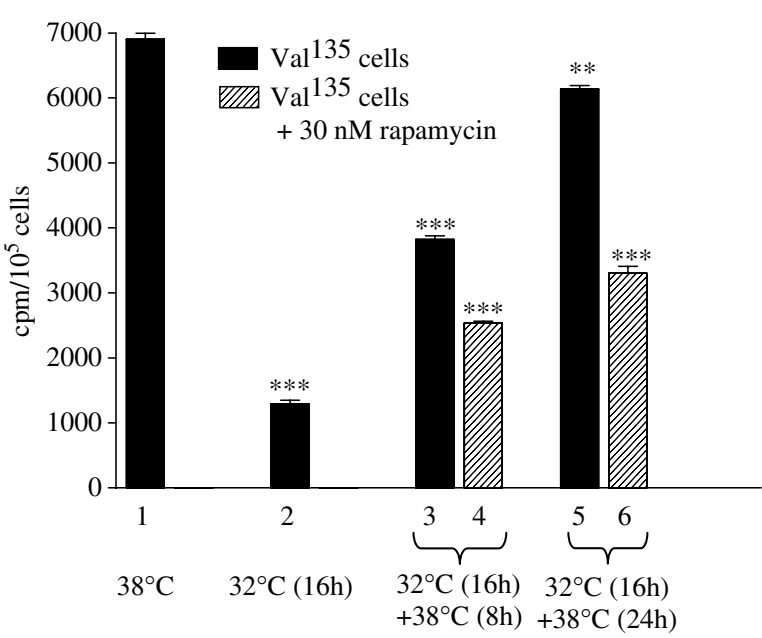

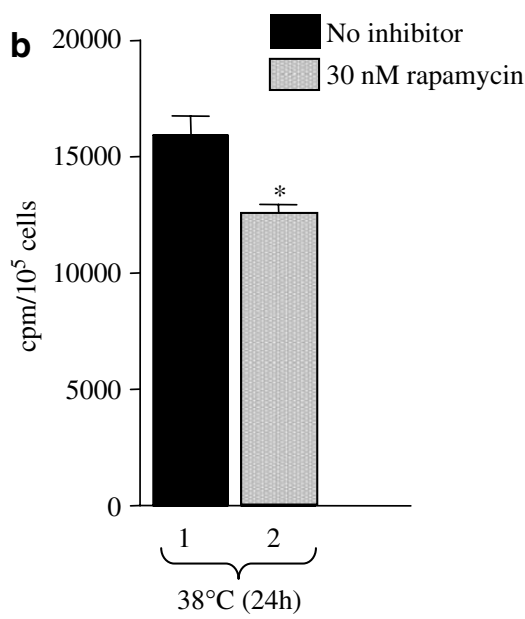

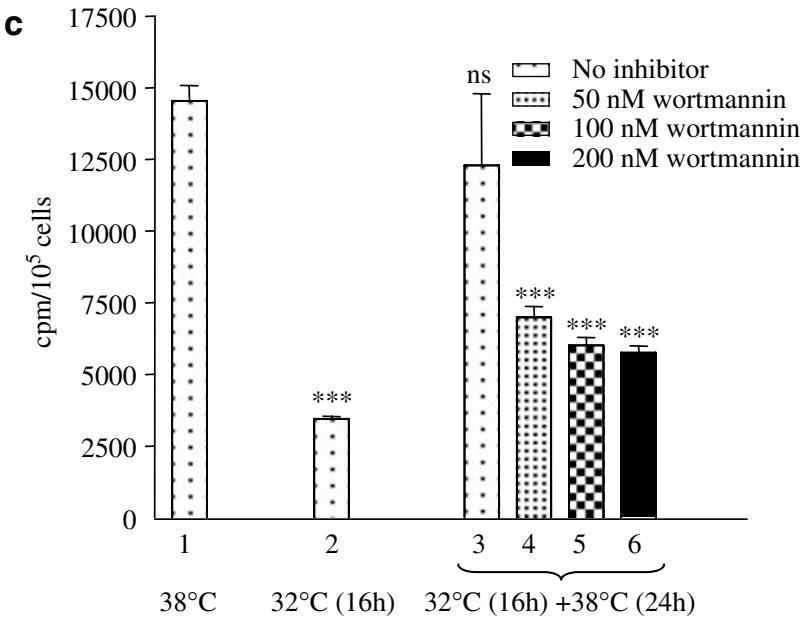

d

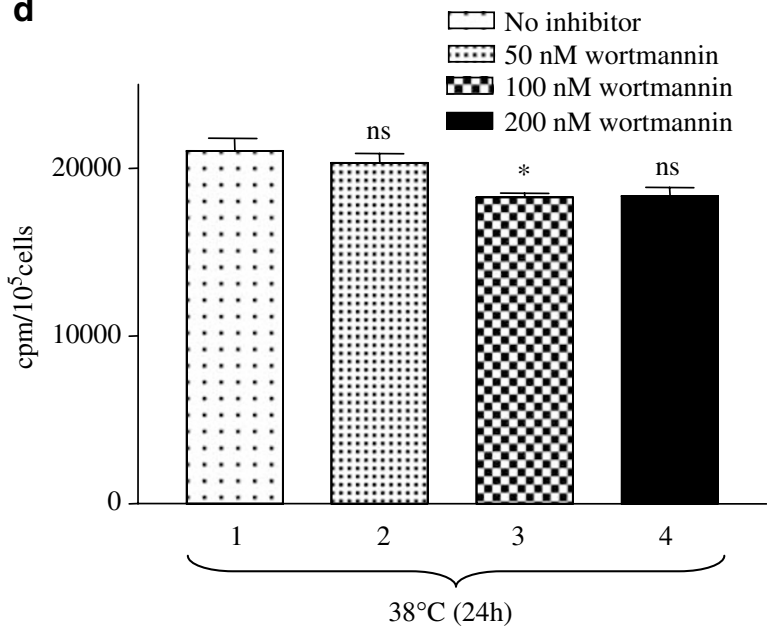

Figure 2 Inhibition by rapamycin and wortmannin of the recovery of protein synthesis following inactivation of $\mathrm{p} 53$. (a) Val ${ }^{135}$ cells that had been incubated at $38^{\circ} \mathrm{C}$ were shifted to $32^{\circ} \mathrm{C}$ for $16 \mathrm{~h}$. The cells were then returned to $38^{\circ} \mathrm{C}$ for the times shown, in the absence (black bars) or presence (shaded bars) of $30 \mathrm{nM}$ rapamycin. (b) Val $\mathrm{l}^{135} \mathrm{cellls}$ that had been maintained at $38^{\circ} \mathrm{C}$ throughout were incubated with or without rapamycin for $24 \mathrm{~h}$. (c) Val ${ }^{135}$ cells that had been incubated at $38^{\circ} \mathrm{C}$ were shifted to $32^{\circ} \mathrm{C}$ for $16 \mathrm{~h}$ and then returned to $38^{\circ} \mathrm{C}$ for $24 \mathrm{~h}$ in the presence of the indicated concentrations of wortmannin. (d) Control cells that had been maintained at $38^{\circ} \mathrm{C}$ throughout were incubated with the same concentrations of wortmannin for $24 \mathrm{~h}$. Rates of protein synthesis were measured as described in Figure 1 . Statistical significances of differences between values were calculated by paired t- test. For panel $\mathbf{a}$, ${ }^{* *}$ indicates $P<0.001$ and ${ }^{* * *}$ indicates $P<0.0001$ for the differences between bars 1 versus 2,1 versus 3,1 versus 5,3 versus 4 and 5 versus 6 ; for panel $\mathbf{b}$, * indicates $P<0.01$ for the difference between bars 1 and 2 ; for panel $\mathbf{c}$, ns indicates not significant and ${ }^{* * *}$ indicates $P<0.0001$ for the differences between bars 1 versus 2,1 versus 3,3 versus 4,3 versus 5 and 3 versus 6 ; for panel $\mathbf{d}$, ns indicates not significant and ${ }^{*}$ indicates $P=0.01$ for the differences between bars 1 versus 2, 1 versus 3 and 1 versus 4 . Note that, at the concentrations employed here, wortmannin has only a minimal direct effect on the activity of $\mathrm{mTOR}^{30,31}$

Effects of rapamycin and wortmannin on the level of initiation factor elF4GI during the recovery of protein synthesis. We have investigated the kinetics of reversal of the various changes in the initiation machinery associated with inhibition of translation by $\mathrm{p} 53 .{ }^{3}$ To examine the rate of reappearance of full-length initiation factor elF4GI and the disappearance of the previously described cleaved form of the factor, ${ }^{3}$ Iysates from Val ${ }^{135}$ cells were analysed by SDS gel electrophoresis and immunoblotting. Two different antielF4GI antibodies were used in this analysis, one of which recognizes only the full-length (uncleaved) factor whereas the other also detects a ca. $80 \mathrm{kDa}$ cleavage product derived from the central region of elF4GI. As shown in Figure $5 \mathrm{a}$ (lanes 2, 3 and 5), restoration of full-length elF4GI did not occur within $8 \mathrm{~h}$ after the shift back to $38^{\circ} \mathrm{C}$ (indeed the signal further decreased), and recovery was less than complete even at $24 \mathrm{~h}$. In contrast the majority of the p53-induced cleavage product of elF4GI, which was detectable after the cells had been incubated at $16 \mathrm{~h}$ at $32^{\circ} \mathrm{C}$, disappeared within $8 \mathrm{~h}$ after p53 was inactivated (Figure 5b, lanes 2, 3 and 5). In view of the low level of elF4GI in cells with active p53 the slow reappearance of the factor during the recovery is likely to be mainly determined by the kinetics of resynthesis. Comparison of the results in Figure 5 with those in Figure 1 suggests that the extent of reappearance of full-length elF4GI may determine the rate of recovery of protein synthesis when p53 is inactivated. However the small residual amount of the intact factor (Figure 5a, lane 3) may 

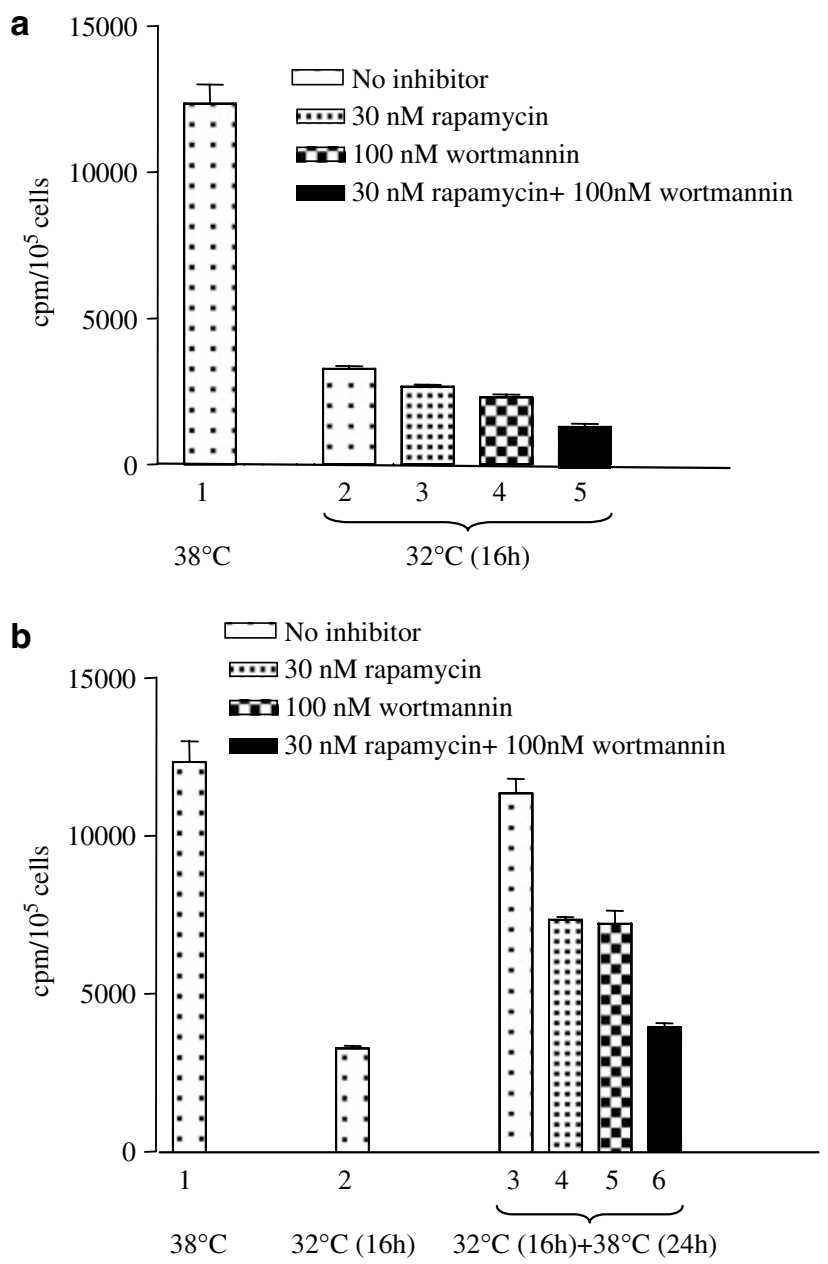

Figure 3 Rapamycin and wortmannin have additive inhibitory effects on the recovery of protein synthesis following inactivation of p53. (a) Val ${ }^{135}$ cells that had been incubated at $38^{\circ} \mathrm{C}$ were shifted to $32^{\circ} \mathrm{C}$ for $16 \mathrm{~h}$ in the absence or presence of rapamycin $(30 \mathrm{nM})$ and/or wortmannin $(100 \mathrm{nM})$ as indicated. (b) Cells that had been incubated at $32^{\circ} \mathrm{C}$ for $16 \mathrm{~h}$ in the absence of inhibitors were returned to $38^{\circ} \mathrm{C}$ for $24 \mathrm{~h}$ in the absence or presence of rapamycin and/or wortmannin. In each case rates of protein synthesis were measured as described in Figure 1. The rates of protein synthesis at $38^{\circ} \mathrm{C}$ in the absence of inhibitors are shown for comparison. Statistical significances of differences between values were calculated by paired $t$ test. For panel a, $P<0.01$ for the difference between bar 1 versus $2, P<0.001$ for the difference between bar 1 versus $3, P<0.0001$ for the differences between bar 1 versus bars 4 and $5, P<0.01$ for the differences between bar 2 versus bars 3 and 5 , $P=0.03$ for the difference between bar 2 versus $4, P<0.01$ for the difference between bar 3 versus $5, P<0.001$ for the difference between bar 4 versus 5 ; for panel $\mathbf{b}, P<0.01$ for the difference between bar 1 versus 2 , there is no significant difference between bars 1 versus $3, P<0.001$ for the difference between bar 3 versus $4, P=0.001$ for the difference between bar 3 versus $5, P<0.0001$ for the difference between bar 3 versus 6 , and $P<0.001$ for the differences between bar 4 versus 6 and bar 5 versus 6

be sufficient to sustain a basal rate of translation and permit some recovery at $8 \mathrm{~h}$, especially since the $80 \mathrm{kDa}$ cleavage product of elF4GI has largely disappeared by this time (Figure $5 b$, lane 3 ).

As rapamycin partially blocks the restoration of protein synthesis following the reversal of p53 activity we examined the effects of this inhibitor on elF4GI levels. Addition of rapamycin when the cells were shifted back to the nonpermissive temperature strongly inhibited the reappearance of full-length elF4GI (Figure 5a, lanes 4 and 6). In contrast the mTOR inhibitor did not prevent loss of the elF4GI cleavage product (Figure 5b, lanes 4 and 6 ). These results suggest that elF4GI synthesis in recovering cells is particularly sensitive to inhibition of mTOR activity. However, rapamycin had little effect on the level of full-length elF4GI in control cells at $38^{\circ} \mathrm{C}$ (Figure $5 \mathrm{c}$ ). This is consistent with the very small effect of the inhibitor on protein synthesis under these conditions (Figure $2 \mathrm{~b}$ ) and may be a reflection of a relatively high stability of elF4GI in the absence of p53 activation.

Wortmannin caused a similar delay in the reappearance of elF4GI (Figure 6a) but, as with rapamycin, did not prevent the disappearance of the cleavage product (Figure 6b). Again these data are consistent with the rate of recovery of protein synthesis being limited by the absence of full-length elF4GI. Wortmannin had little effect on the level of elF4GI in control cells at $38^{\circ} \mathrm{C}$ (Figure 6c). PD98059, SB203580 and CGP74514A all had only minor effects on the reappearance of full-length elF4GI during the recovery period (data not shown). These results argue against a major role for pathways dependent on Mek1/2 kinase, p38 MAP kinase or cdc2 kinase activities in the regulation of elF4GI levels.

Figure 6a (middle panel) also shows that when the $\mathrm{Val}^{135}$ cells were shifted to $32^{\circ} \mathrm{C}$ initiation factor elF4GI was dephosphorylated at $\mathrm{Ser}^{1108}$. Complete rephosphorylation of this site took place within $24 \mathrm{~h}$ when the cells were returned to the nonpermissive temperature, but this was prevented in the presence of either rapamycin or wortmannin.

Regulation of 4E-BP1 and its association with elF4E during the recovery of protein synthesis. Activation of p53 causes both the dephosphorylation of 4E-BP1 and the cleavage of this protein to generate two truncated forms. Both the hypophosphorylated full-length and the larger cleaved form of the protein bind to elF4E. ${ }^{3}$ To examine the integrity and state of phosphorylation of 4E-BP1 during the recovery of protein synthesis, cell extracts were separated on SDS gels and immunoblotted with antibodies to total and phosphorylated 4E-BP1. Figure 7a (top panel) shows that the truncated forms of $4 \mathrm{E}-\mathrm{BP} 1$ partially disappeared within $8 \mathrm{~h}$ after the return of the cells to $38^{\circ} \mathrm{C}$ and were completely lost by $24 \mathrm{~h}$. Extensive dephosphorylation at $\mathrm{Ser}^{64}$, and partial dephosphorylation at $\mathrm{Thr}^{69}$ and $\mathrm{Thr}^{36 / 45}$, occurred at $32^{\circ} \mathrm{C}$ but reincubation at $38^{\circ} \mathrm{C}$ resulted in complete rephosphorylation of the full-length protein at all these sites within $8 \mathrm{~h}$ (Figure $7 \mathrm{a}$ and Supplementary Figure 1). This indicates rapid reversal of the activities of 4E-BP1-specific protein kinases and/or phosphatases that are regulated by p53. In contrast, even though the truncated forms of 4E-BP1 were still detectable at $8 \mathrm{~h}$, no re-phosphorylation of these proteins took place (Figure $7 \mathrm{a}$, lane 3 ). This indicates that these forms of 4E-BP1 remain irreversibly hypophosphorylated at $\mathrm{Ser}^{64}, \mathrm{Thr}^{69}$ and $\mathrm{Thr}^{36 / 45}$ under conditions where the full-length protein does become re-phosphorylated. This may delay the release of elF4E from the inhibitory effect of the larger truncated form of $4 \mathrm{E}-\mathrm{BP} 1$, to which the initiation factor is bound (see below). 

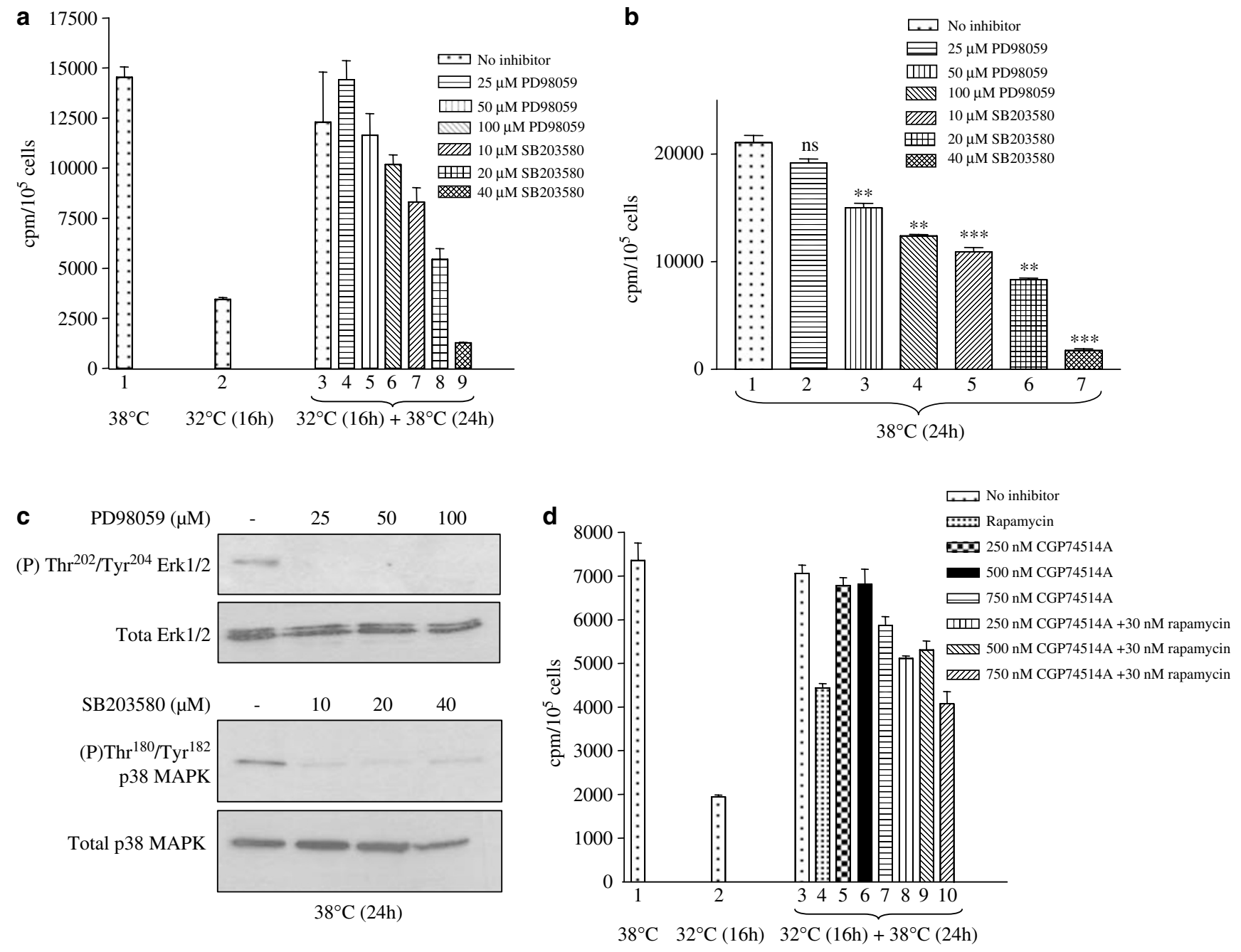

e $\quad$ CGP74514A $(\mathrm{nM})$

(P) $\mathrm{Thr}^{161} \mathrm{cdc} 2$

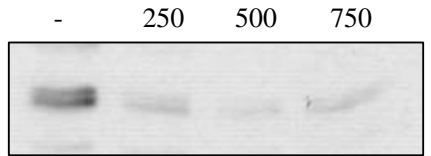

Total cdc2

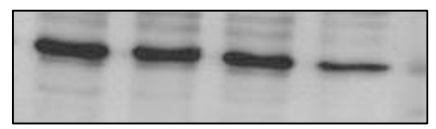

$38^{\circ} \mathrm{C}(24 \mathrm{~h})$

Figure 4 Effects of inhibitors of Mek1/2 kinases, p38 MAP kinase and cdc2 kinase on the recovery of protein synthesis after inactivation of p53. (a) Val ${ }^{135}$ cells that had been growing at $38^{\circ} \mathrm{C}$ were shifted to $32^{\circ} \mathrm{C}$ for $16 \mathrm{~h}$. The cells were then returned to $38^{\circ} \mathrm{C}$ for $24 \mathrm{~h}$ in the absence or presence of PD98059 or SB203580 at the concentrations indicated. (b) Val ${ }^{135}$ cells were maintained at $38^{\circ} \mathrm{C}$ and incubated for $24 \mathrm{~h}$ in the absence or presence of the same inhibitor concentrations as in (a). (c) Extracts prepared from cells incubated with the indicated concentrations of PD98059 or SB203580 were analysed by SDS gel electrophoresis and immunoblotting for phosphorylated Erk1/2 $\left(\mathrm{Thr}^{202} / \mathrm{Tyr}^{204}\right)$, total Erk1/2, phosphorylated p38 MAPK $\left(\mathrm{Thr}^{180} / \mathrm{Tyr}^{182}\right.$ ) and total p38 MAPK as indicated. (d) Val ${ }^{135}$ cells were treated as in (a), except that CGP74514A was added at the concentrations indicated, in the absence or presence of rapamycin $(30 \mathrm{nM})$. (e) Extracts prepared from cells incubated with the indicated concentrations of CGP74514A were analysed by SDS gel electrophoresis and immunoblotting for phosphorylated cdc2 (Thr ${ }^{161}$ ) and total cdc2 as indicated. Rates of protein synthesis (panels $\mathbf{a}, \mathbf{b}$ and $\mathbf{d}$ ) were measured as described in Figure 1. Statistical significances of differences between values were calculated by paired t test. For panel $\mathbf{a}, P<0.001$ for the difference between bar 1 versus 2, there is no significant difference between bar 1 versus 3 or between bar 3 versus bars 4 and $5, P<0.01$ for the difference between bar 3 versus $6, P=0.02$ for the difference between bar 3 versus $7, P<0.001$ for the difference between bar 3 versus 8 , and $P<0.0001$ for the difference between bar 3 versus 9 ; for panel $\mathbf{b}$, ns indicates not significant, ${ }^{* *}$ indicates $P<0.01$ and ${ }^{* * *}$ indicates $P<0.0001$ for the differences between bar 1 versus the bars shown; for panel $\mathbf{d}, P<0.001$ for the difference between bar 1 versus 2, there is no significant difference between bar 1 versus 3 or between bar 3 versus bars 5 and $6, P<0.02$ for the difference between bar 3 versus $7, P<0.01$ for the difference between bar 3 versus $8, P<0.001$ for the differences between bar 3 versus bars 4 and 10 , and $P<0.0001$ for the difference between bar 3 versus 9 


\section{a}

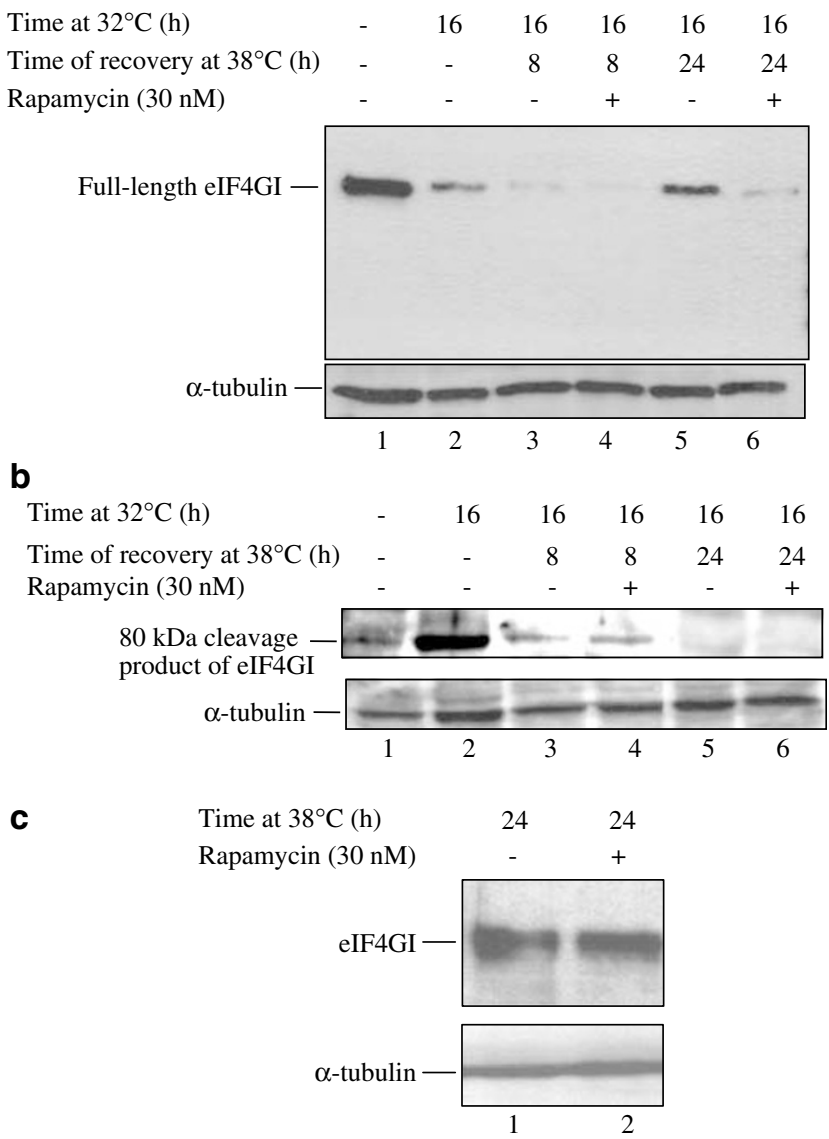

Figure 5 Inhibition by rapamycin of the reappearance of full-length initiation factor elF4GI during the recovery of protein synthesis from inhibition by $\mathrm{p} 53$. Val ${ }^{135}$ cells that had been grown at $38^{\circ} \mathrm{C}$ (lane 1) were shifted to $32^{\circ} \mathrm{C}$ for $16 \mathrm{~h}$ (lane 2 ) and then returned to $38^{\circ} \mathrm{C}$ for $8 \mathrm{~h}$ (lanes 3 and 4 ) or $24 \mathrm{~h}$ (lanes 5 and 6). Where indicated (lanes 4 and 6$)$, rapamycin $(30 \mathrm{nM})$ was added when the cells were returned to $38^{\circ} \mathrm{C}$. Cell extracts were prepared as described in Materials and Methods, separated on SDS polyacrylamide gels and immunoblotted for (a) fulllength elF4GI or (b) the ca. $80 \mathrm{kDa}$ cleavage product of elF4GI. The blots were then re-probed for $\alpha$-tubulin as a loading control. The positions of the relevant bands are indicated. (c) Cells that had been maintained at $38^{\circ} \mathrm{C}$ throughout were incubated with or without rapamycin for $24 \mathrm{~h}$ and extracts were blotted for full-length elF4GI and $\alpha$-tubulin as above

We also investigated the effects of rapamycin and other signal transduction inhibitors on the rephosphorylation of $4 \mathrm{E}$ BP1. Figure 7a and Supplementary Figure 1 show that upon return of the $\mathrm{Val}^{135}$ cells to the nonpermissive temperature full-length 4E-BP1 became partially rephosphorylated at $\mathrm{Ser}^{64}, \mathrm{Thr}^{69}$ and $\mathrm{Thr}^{36 / 45}$ even in the presence of rapamycin. These data suggest that although the rephosphorylation of these sites probably requires an active mTOR-raptor complex, other protein kinases, or possibly a rapamycin-resistant form of mTOR, are also involved. Similar analyses of 4E-BP1 rephosphorylation were performed on cells restored to $38^{\circ} \mathrm{C}$ in the presence of wortmannin. However in this case the data were difficult to interpret because of a major loss of total 4E-BP1 protein (data not shown).

PD98059, SB203580 and CGP74514A all inhibited the rephosphorylation of full-length $4 \mathrm{E}-\mathrm{BP} 1$ to some extent a

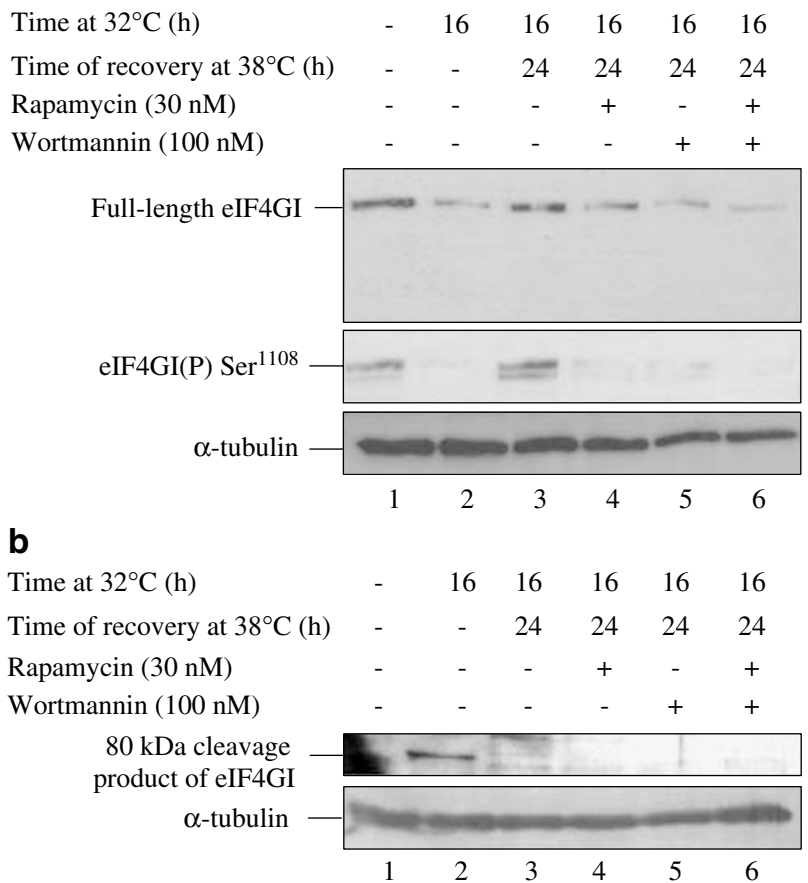

C

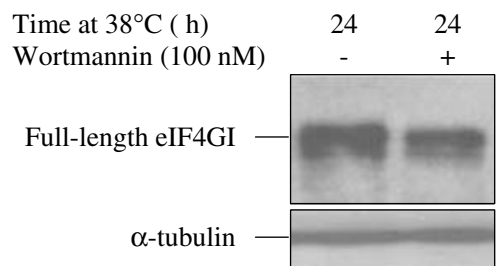

Figure 6 Inhibition by rapamycin and wortmannin of the reappearance and rephosphorylation of full-length elF4GI during the recovery phase of protein synthesis. Val ${ }^{135}$ cells that had been grown at $38^{\circ} \mathrm{C}$ were shifted to $32^{\circ} \mathrm{C}$ for $16 \mathrm{~h}$. The cells were then returned to $38^{\circ} \mathrm{C}$ and incubated in the absence or presence of rapamycin $(30 \mathrm{nM})$ and/or wortmannin $(100 \mathrm{nM})$ for $24 \mathrm{~h}$. Cell extracts were prepared as described in Materials and Methods, separated on SDS polyacrylamide gels and immunoblotted for (a) total full-length elF4GI and elF4GI phosphorylated at $\mathrm{Ser}^{1108}$ and (b) the ca. $80 \mathrm{kDa}$ cleavage product of elF4Gl. The blots were then re-probed for $\alpha$-tubulin as a loading control. The positions of the relevant bands are indicated. (c) $\mathrm{Val}^{135}$ cells that had been maintained at $38^{\circ} \mathrm{C}$ throughout were incubated with or without wortmannin for $24 \mathrm{~h}$ and extracts were blotted for total fulllength elF4GI and $\alpha$-tubulin as above

(especially at $\mathrm{Ser}^{64}$ ) when the $\mathrm{Val}^{135}$ cells were restored to $38^{\circ} \mathrm{C}$ (Figure $7 \mathrm{~b}$ ). The effects of PD98059 and CGP74514A are consistent with previous observations that 4E-BP1 can be phosphorylated by the Erks ${ }^{6}$ and cdc2 kinase. ${ }^{7}$ As indicated above, however, neither Mek/Erk inhibition nor cdc2 inhibition impaired the recovery of protein synthesis (Figure 4). These results lead us to conclude that the availability of elF4E (i.e. in a form not complexed with 4E-BP1) must be adequate to meet the translational demand $24 \mathrm{~h}$ after the shift back to $38^{\circ} \mathrm{C}$, even when the activities of the Erk and cdc2 kinases are compromised.

Cell extracts were also analysed for the extent of association of 4E-BP1 with elF4E, using $\mathrm{m}^{7}$ GTP-Sepharose affinity chromatography. Figure $8 \mathrm{a}$ shows that, surprisingly, there was relatively little change in the binding of full-length 4E-BP1 


$\begin{array}{lcccccc}\text { Time at } 32^{\circ} \mathrm{C} & - & 16 & 16 & 16 & 16 & 16 \\ \text { Time of recovery at } 38^{\circ} \mathrm{C} & - & - & 8 & 8 & 24 & 24 \\ \text { Rapamycin }(30 \mathrm{nM}) & - & - & - & + & - & +\end{array}$
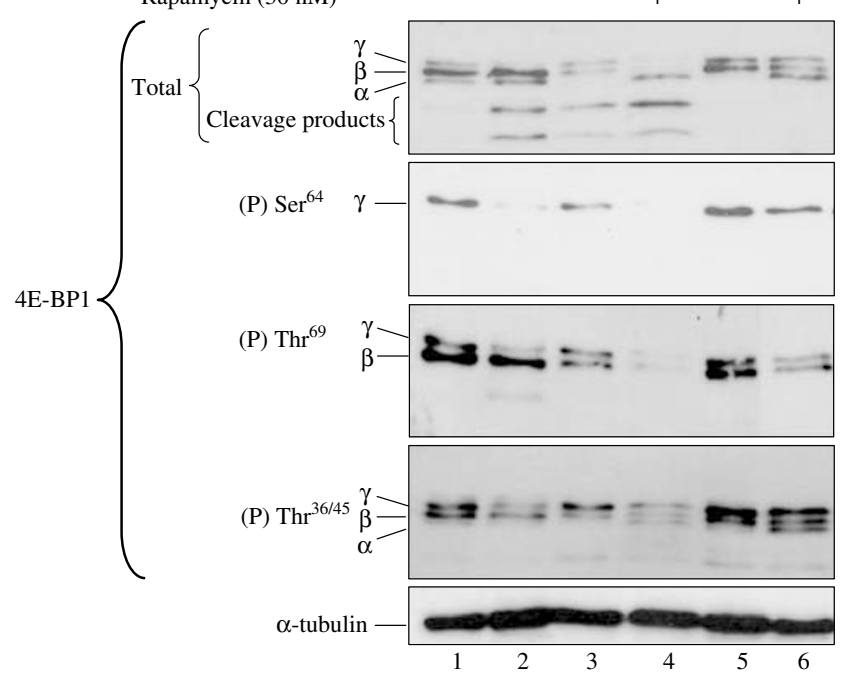

b

$\begin{array}{lcccccc}\text { Time at } 32^{\circ} \mathrm{C}(\mathrm{h}) & - & 16 & 16 & 16 & 16 & 16 \\ \text { Time of recovery at } 38^{\circ} \mathrm{C}(\mathrm{h}) & - & - & 24 & 24 & 24 & 24 \\ \text { PD98059 }(100 \mu \mathrm{M}) & - & - & - & + & - & - \\ \mathrm{SB} 203580(20 \mu \mathrm{M}) & - & - & - & - & + & - \\ \text { CGP74514A }(750 \mathrm{nM}) & - & - & - & - & - & +\end{array}$

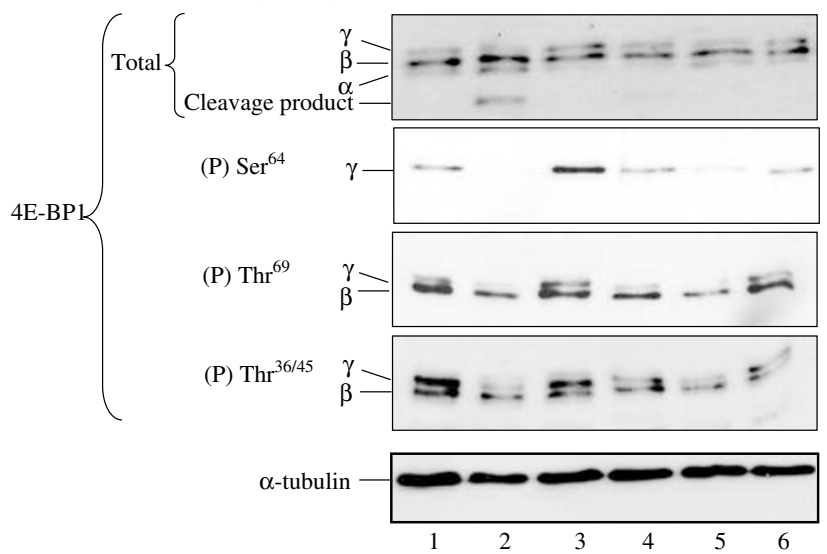

Figure 7 Changes in the integrity and phosphorylation of 4E-BP1 during the recovery phase of protein synthesis and effects of inhibitors of signal transduction pathways. (a) Val ${ }^{135}$ cells that had been grown at $38^{\circ} \mathrm{C}$ were shifted to $32^{\circ} \mathrm{C}$ for $16 \mathrm{~h}$ and then returned to $38^{\circ} \mathrm{C}$ for $8 \mathrm{~h}$ or $24 \mathrm{~h}$, in the absence or presence of rapamycin $(30 \mathrm{nM})$. Cell extracts were prepared, separated on SDS polyacrylamide gels and immunoblotted for total 4E-BP1 and 4E-BP1 phosphorylated on $\mathrm{Ser}^{64}{ }^{64} \mathrm{Th}^{69}$ and $\mathrm{Th}^{36 / 45}$. The positions of the differentially phosphorylated $\alpha, \beta$ and $\gamma$ forms of fulllength $4 \mathrm{E}-\mathrm{BP} 1$ and of two truncated forms (cleavage products) are indicated. The blots were re-probed for $\alpha$-tubulin as a loading control. (b) Val ${ }^{135}$ cells that had been grown at $38^{\circ} \mathrm{C}$ were shifted to $32^{\circ} \mathrm{C}$ for $16 \mathrm{~h}$ and then returned to $38^{\circ} \mathrm{C}$ for $24 \mathrm{~h}$, in the absence or presence of PD98058 $(100 \mu \mathrm{M})$, SB203580 $(20 \mu \mathrm{M})$ or CGP74514A $(750 \mathrm{nM})$ as indicated. Cell extracts were prepared and immunoblotted as in (a). The positions of the differentially phosphorylated $\alpha, \beta$ and $\gamma$ forms of full-length 4E-BP1 and of the larger truncated form (cleavage product) are indicated

to elF4E when the cells were shifted between 38 and $32^{\circ} \mathrm{C}$ and vice versa. It was notable that the larger truncated form of 4E-BP1 bound strongly to elF4E after activation of p53, and remained associated with the factor at the $8 \mathrm{~h}$ recovery time

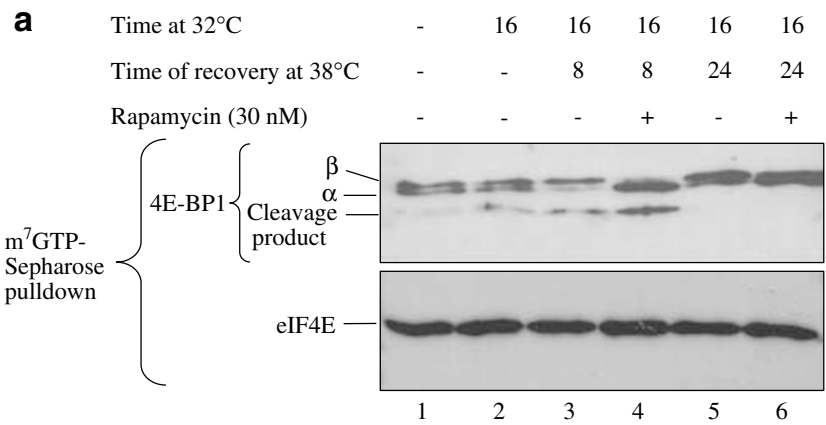

b

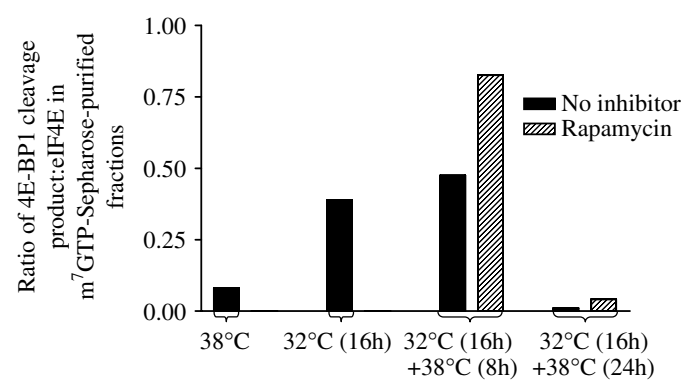

Figure 8 Binding of full-length and truncated 4E-BP1 to elF4E during the recovery phase of protein synthesis. Val ${ }^{135}$ cells that had been grown at $38^{\circ} \mathrm{C}$ were shifted to $32^{\circ} \mathrm{C}$ for $16 \mathrm{~h}$ and then returned to $38^{\circ} \mathrm{C}$ for $8 \mathrm{~h}$ or $24 \mathrm{~h}$, in the absence or presence of rapamycin $(30 \mathrm{nM})$. Cell extracts were prepared and $\mathrm{m}^{7} \mathrm{GTP}$ Sepharose affinity chromatography performed as described in Materials and Methods. (a) Affinity-purified fractions obtained from equal amounts of cell extract were separated on SDS polyacrylamide gels and immunoblotted for total 4E-BP1 and elF4E as indicated. (b) The band intensities of the bound cleavage product of $4 \mathrm{E}-\mathrm{BP} 1$ and of elF4E in the $\mathrm{m}^{7} \mathrm{GTP}$-Sepharose-purified fractions were quantified by densitometry and are shown as ratios

point (Figure 8a, lanes 2 and 3 and Figure $8 b$ ). However at $24 \mathrm{~h}$ no truncated 4E-BP1 remained associated with elF4E (Figure 8a, lanes 5 and 6 ). The smaller truncated form of 4E-BP1 did not bind to elF4E under any conditions. Addition of rapamycin at the time of the shift back to $38^{\circ} \mathrm{C}$ increased the extent of binding of the larger truncated form to elF4E at $8 \mathrm{~h}$ (Figure 8a, lanes 3 and 4 , and Figure $8 \mathrm{~b}$ ), but the inhibitor did not prevent the loss of this binding at $24 \mathrm{~h}$ (Figure $8 \mathrm{a}$, lanes 5 and 6 ). Although rapamycin delayed the rephosphorylation of full-length 4E-BP1, and increased the binding of this protein to elF4E at $8 \mathrm{~h}$, it had no effect on the binding of 4E-BP1 to elF4E at $24 \mathrm{~h}$ (Figure $8 \mathrm{a}$, compare lanes 5 and 6 ). The latter result suggests that the ability of rapamycin to inhibit the recovery of protein synthesis at $24 \mathrm{~h}$ (and later time points) cannot be ascribed to regulation of the availability of elF4E by either full-length or truncated 4E-BP1.

\section{Discussion}

Signalling pathways required for recovery of protein synthesis from p53-induced inhibition. The gradual recovery of protein synthesis that occurs when p53 is inactivated is consistent with our previous conclusion that MEL cells are not irreversibly committed to apoptosis or loss of viability by activation of p53 for up to $16 \mathrm{~h} .^{2}$ This indicates that the signal transduction pathways and mechanisms for 
the restoration of the activity of the translational apparatus are not irreversibly compromised within this time frame.

We previously concluded that inhibition of mTOR activity plays only a minor role in mediating the inhibitory effects of p53. ${ }^{3}$ However, exposure of the cells to rapamycin upon returning them to the nonpermissive temperature partially inhibits the recovery of protein synthesis, to an extent which is much greater than the inhibition observed in cells incubated throughout at $38^{\circ} \mathrm{C}$. These data suggest that the rapamycinsensitive mTOR-raptor complex plays a more significant role in cells recovering from the effects of this physiological stress than in control cells. One possible reason is that mTOR may selectively regulate the translation of mRNAs encoding components of the translation machinery which are depleted as a result of p53 activation. ${ }^{8}$ We have shown here that rapamycin strongly impairs the restoration of the level of elF4GI following inactivation of p53 (Figures 5 and 6) and new synthesis of this factor is likely to be required for the reacquisition of full translational capacity. The fact that rapamycin does not fully prevent the recovery of protein synthesis suggests, in addition, the existence of one or more pathways for translational regulation by p53 that are independent of rapamycin-sensitive mTOR. This is in agreement with the distinct and additive effects of p53 activation and rapamycin treatment on 4E-BP1 dephosphorylation, elF4F complex formation and protein synthesis rates in MEL cells. ${ }^{3}$ The low residual level of elF4Gl present in cells at $8 \mathrm{~h}$ of recovery (and at later times also in rapamycin-treated cells) may be sufficient to sustain a basal rate of protein synthesis and allow a small degree of recovery but this level is likely to be rate-limiting for translation at later time points.

Wortmannin also partially prevents the recovery of protein synthesis following the inactivation of $\mathrm{p} 53$, and this inhibition is likewise associated with the failure of elF4GI to be restored to control levels (Figure 6). The mechanism whereby PI3k activity influences elF4GI synthesis is unclear. It may act via regulation of downstream Akt, which in turn acts on $\mathrm{mTOR},{ }^{9}$ but the involvement of one or more additional pathways is also likely. We favour the latter interpretation because: (i) we have not seen any evidence for inhibition of Akt activity in cells with activated $\mathrm{p5} 3^{1}$; (ii) there is no decrease in the phosphorylation of Akt on $\operatorname{Ser}^{473}$ (a site associated with activation of this protein kinase) following p53 activation, although there is hyperphosphorylation of this site during the recovery phase (Supplementary Figure 2); and (iii) the effects of wortmannin and rapamycin on protein synthesis during recovery are additive, suggesting an mTOR-independent mode of action of the PI3K inhibitor. Interestingly, mTOR-independent but PI3k-dependent phosphorylation of 4E-BP1 has previously been reported. ${ }^{10}$ Whatever the mechanism it is important to note that, although the PI3k/Akt pathway provides an important survival signal for MEL cells, ${ }^{11}$ neither rapamycin nor wortmannin significantly affects the level of elF4GI in exponentially growing control cells (Figures $5 c$ and $6 c$ ).

Mek1/2 kinase activity is not required for restoration of translation when p53 is inactivated and we have observed increases rather than decreases in the levels of activating phosphorylations of both Mek $1 / 2$ and Erk1/2 kinases following the shift of cells to $32^{\circ} \mathrm{C}$ (Supplementary Figure 3 ). This is consistent with the conclusion that Mek and Erk activity is required for $\mathrm{p} 53$-dependent apoptosis in this system. ${ }^{12}$ The ability of PD98059 to inhibit the rephosphorylation of fulllength 4E-BP1 but not block the recovery of protein synthesis at $38^{\circ} \mathrm{C}$ suggests that the extent of phosphorylation of 4E-BP1 (particularly at Ser ${ }^{64}$ ) is not critical in controlling the availability of elF4E for translation under these conditions.

Although there are indications that cdc2 activity is inhibited by the activation of $p 53$ in MEL cells, ${ }^{3}$ CGP74514A was ineffective in blocking the recovery of protein synthesis (Figure 4d). Nevertheless, there was some inhibition of the rephosphorylation of $\mathrm{Ser}^{64}$ in cells returned to $38^{\circ} \mathrm{C}$ in the presence of the cdc2 inhibitor (Figure $7 b$ ), again suggesting that the impairment of $\mathrm{Ser}^{64}$ phosphorylation is not critical to the recovery process.

We have not been able to assess the specific importance of the p38 MAP kinase pathway in the response of MEL cells to p53 because SB203580 was also strongly inhibitory for protein synthesis in control cells (Figure 4b). However, p53 activation caused only a very small decrease in the activity of p38 MAP kinase (as judged by the state of phosphorylation of this protein on $\mathrm{Thr}^{180} / \mathrm{Tyr}^{182}$ ) (Supplementary Figure 4).

Relative roles of elF4GI and 4E-BP1 modifications in regulation of translation by $\mathbf{p 5 3}$. Our data suggest that, whereas during the first $8 \mathrm{~h}$ of recovery the binding of the larger truncated form of 4E-BP1 to elF4E may limit the rate of protein synthesis, at later times (when this protein has disappeared) the submaximal rates of protein synthesis are more likely to be due to the lack of full-length elF4GI. This conclusion is confirmed by the effects of rapamycin and wortmannin, which block the restoration of full-length elF4GI. In addition, the fact that the elF4GI cleavage product disappears well in advance of the recovery of translation indicates that the slow restoration of protein synthesis is not attributable to the effects of this protein.

The mechanisms by which the restoration of elF4GI is inhibited by rapamycin or wortmannin remain to be established. There are several precedents for the sensitivity of translation of specific mRNAs to inhibitors of the PI3k/mTOR pathway and microarray and other studies have revealed a large number of mRNAs that are translationally repressed by rapamycin. ${ }^{13}$ These include mRNAs encoding ribosomal proteins, as well as polypeptide chain initiation factors elF4A, elF5A and elF2B $\varepsilon .{ }^{13,14}$ In the case of elF4GI the mRNA for this large protein can be translated by internal initiation under certain conditions and this might be expected to render the synthesis of elF4GI insensitive to rapamycin. Curiously, however, the internal ribosome entry site-mediated translation of elF4GI still demonstrates cap-dependence. ${ }^{15}$ It has also been suggested that rapamycin causes decreased transcription of the elF4G gene and, additionally, can enhance the rate of proteolysis of the initiation factor. ${ }^{16,17}$ We cannot formally rule out the possibility that rapamycin regulates the expression of elF4GI by such mechanisms. Nevertheless, in the absence of $\mathrm{p} 53$ activation neither rapamycin nor wortmannin has any effect on the level of the protein (Figures $5 c$ and $6 c$ ).

Upon return of the cells to $38^{\circ} \mathrm{C}$ full-length 4E-BP1 becomes rapidly rephosphorylated at all sites examined (Figure 7 and Supplementary Figure 1). This occurs well before protein synthesis is fully restored suggesting that, at later time points, 
the state of phosphorylation of 4E-BP1 may be less important than the level or integrity of elF4GI in determining the overall rate of translation. Even in the presence of rapamycin partial rephosphorylation of 4E-BP1 occurred within $24 \mathrm{~h}$, providing evidence that one or more kinases other than rapamycinsensitive mTOR must be involved in regulating the phosphorylation of the translational repressor. It is possible that different protein kinases may phosphorylate different sites on 4E$\mathrm{BP} 1,{ }^{18}$ and/or that both rapamycin-sensitive and -insensitive forms of $\mathrm{mTOR}^{19}$ are involved.

In spite of the changes in the phosphorylation of 4E-BP1 there is relatively little difference in the amounts of full-length 4E-BP1 bound to elF4E in cells shifted from 38 to $32^{\circ} \mathrm{C}$ and back again (Figure $8 \mathrm{a}$ ). This argues against a major role for 4E-BP1 phosphorylation in regulating protein synthesis in MEL cells following changes in p53 activity. Consistent with this, PD98059 and CGP74514A inhibit the rephosphorylation of $4 \mathrm{E}-\mathrm{BP} 1$ (especially at $\mathrm{Ser}^{64}$ ) without impairing the recovery of protein synthesis. However, the larger cleavage product of 4E-BP1 present in cells with active p53 (reference 3 and Figure 7) binds strongly to elF4E (Figure 8a) and may limit the availability of the latter during the early phase of recovery. Addition of rapamycin at the time of shifting the cells back to $38^{\circ} \mathrm{C}$ increases the binding of this protein to elF4E at $8 \mathrm{~h}$ (Figure 8a). However, the truncated 4E-BP1 is lost after $24 \mathrm{~h}$ of recovery and cannot therefore be responsible for the continuing depressed rate of translation at this time.

Significance for p53-mediated cellular responses to physiological stresses. The activation of $p 53$ by cellular stresses such as DNA damage is well known to induce cell growth arrest and/or apoptosis, and the shut-down of protein synthesis can be viewed as a component of both these effects. However, even when the eventual outcome is cell death there is an initial period during which the effects of p53 are reversible, at least in transformed cells. ${ }^{20,21} \mathrm{MEL}$ cells do not become committed to apoptosis until at least $16 \mathrm{~h}$ after the activation of the tumour suppressor protein. ${ }^{2}$ Moreover, in another system utilizing inducible p53, where protein synthesis is strongly impaired following induction, there is no obvious apoptosis for up to 4 days. ${ }^{22}$ The ability to rephosphorylate 4E-BP1, resynthesise elF4GI and restore the rate of protein synthesis after inactivation of p53 is likely to be an important factor in cellular recovery.

Interestingly, a recent report ${ }^{23}$ has shown that overexpression of elF4E can inhibit p53-mediated transcription and the initiation of apoptosis. This may be explained by the promotion of the synthesis of anti-apoptotic proteins such as p21 and survivin, the translation of which is particularly dependent on mTOR activity. ${ }^{13,24}$ Our results, in conjunction with these data, suggest that an amplification loop may exist whereby the activation of $\mathrm{p} 53$ inhibits elF4E function (via dephosphorylation of 4E-BP1 and the loss of elF4G) and this in turn allows p53 to remain active for longer. However, in tumours where elF4E is over-expressed, ${ }^{25-27}$ or where the $\mathrm{PI3k} / \mathrm{Akt} / \mathrm{mTOR}$ pathway is hyperactive, ${ }^{28}$ such positive feedback may be inhibited and the cells would thus be more resistant to the effects of p53 activation. This could explain the anti-apoptotic and transforming effects of high levels of elF4E.

\section{Materials and Methods}

Cell Culture Conditions. The Val ${ }^{135}$ and Pro ${ }^{190} \mathrm{MEL}$ cell lines were obtained from $\mathrm{Dr} S$ Benchimol ${ }^{29}$ and were grown in stationary suspension culture in DMEM medium supplemented with glutamine $(300 \mathrm{mg} / \mathrm{L})$ and $10 \%(\mathrm{v} / \mathrm{v})$ foetal bovine serum in a $5 \% \mathrm{CO}_{2}$ atmosphere at $38^{\circ} \mathrm{C}$. Under these conditions the expressed p53 was inactive and the cells grew exponentially with a doubling time of $12 \mathrm{~h}$. Cultures were maintained at densities between 2 and $10 \times 10^{5}$ cells per $\mathrm{ml}$. Continued expression of p53 was assured by weekly selection of the cells in $\mathrm{G} 418(200 \mu \mathrm{g} / \mathrm{ml})$. For activation of p53 in the $\mathrm{Val} 1^{135}$ cells the cultures were transferred to $32^{\circ} \mathrm{C}$ for the times indicated. The control Pro ${ }^{190}$ cells (in which the p53 is inactive at both temperatures) were treated similarly. The inhibitors rapamycin, wortmannin, PD98059, SB203580 and CGP74514A (Calbiochem) were added to the cells at the concentrations and for the times described in the figure legends.

Measurement of protein synthesis rates. Cells were counted in a haemocytometer and overall rates of protein synthesis were then measured by pulse labelling for $1 \mathrm{~h}$ with $6-10 \mu \mathrm{C}_{\mathrm{j}} / \mathrm{ml}$ of $\left.{ }^{35} \mathrm{~S}\right]$ methionine (in the presence of the normal level of methionine in the cell culture medium). After the incubation $300 \mu \mathrm{l}$ of cells were added to $5 \mathrm{ml}$ of phosphate-buffered saline (PBS) and centrifuged at 1000 r.p.m. for $10 \mathrm{~min}$. The supernatant was removed and the cells were precipitated with $10 \%$ trichloroacetic acid. Precipitates were harvested on GF/C filters under suction and washed with $5 \%$ trichloroacetic acid and industrial methylated spirit. The acid-insoluble radioactivity was determined by liquid scintillation counting. For each condition three incubations were carried out in duplicate and the data are shown as means \pm S.E.M. of the counts per min incorporated per $10^{5}$ cells. Significances of differences between rates of protein synthesis were calculated by paired $t$ test and the $P$-values are indicated in the figure legends.

Preparation of cell extracts and analysis by immunoblotting. Cytoplasmic extracts were prepared for immunoblotting by washing $1 \times 10^{7}$ cells in $1 \mathrm{ml}$ of PBS and resuspending the pellet in $500 \mu \mathrm{l}$ of cell lysis buffer $(50 \mathrm{mM}$ MOPS, $50 \mathrm{mM} \mathrm{NaCl}, 2 \mathrm{mM}$ EDTA, $2 \mathrm{mM}$ EGTA, $50 \mathrm{mM}$ $\beta$-glycerophosphate) and $10 \mu \mathrm{l}$ of $10 \% \mathrm{NP} 40$ containing the following phosphatase and proteinase inhibitors: one tablet of protease inhibitors (Complete Mini, EDTA-free protease inhibitor cocktail, Roche) per $10 \mathrm{ml}$ of cell lysis buffer, $2 \mathrm{mM}$ sodium vanadate, $1 \mu \mathrm{M}$ microcystin, $7 \mathrm{mM}$ 2-mercaptoethanol and $1 \mathrm{mM}$ phenylmethylsulphonylfluoride. After centrifugation for $5 \mathrm{~min}$ at $9200 \times \mathrm{g}$ to pellet the nuclei the cytoplasmic extracts were analysed by SDS gel electrophoresis, loading equal amounts of protein in each lane of the gel (10-20 $\mu \mathrm{g}$ of protein per sample). The proteins were transferred to poly(vinylidene difluoride) membranes and the blots were blocked and then incubated with the appropriate primary antibodies. Antibodies against elF4GI (central region) and elF4E were kindly provided by $\mathrm{Dr}$ Simon Morley. Additional antibodies against elF4GI (N-terminal region), phospho-elF4GI $\left(\mathrm{Ser}^{1108}\right)$, total Akt, phospho-Akt $\left(\mathrm{Ser}^{473}\right)$, total Mek1/2, phospho-Mek1/2 $\left(\mathrm{Ser}^{217 / 221}\right)$, total Erk1/2, phospho-Erk1/2 $\left(\mathrm{Thr}^{202} / \mathrm{Tyr}^{204}\right)$, total p38 MAPK, phospho-p38 MAPK $\left(\mathrm{Thr}^{180} / \mathrm{Tyr}^{182}\right)$, total cdc2 and phospho-cdc2 $\left(\right.$ Thr $\left.^{161}\right)$ were purchased from Cell Signaling Technology. Antibodies against 4E-BP1 and $\alpha$-tubulin were purchased from Santa Cruz and Sigma, respectively. All blots were developed with horseradish peroxidase-linked secondary antibodies using enhanced chemiluminescence (Cell Signaling Technology). Blots were analysed for $\alpha$-tubulin as a loading control.

$\mathbf{m}^{7}$ GTP-Sepharose affinity chromatography. $50 \%$ (v/v) $\mathrm{m}^{7} \mathrm{GTP}$ Sepharose 4B resin (Amersham) was washed in PBS and resuspended in cell lysis buffer. $50 \mu \mathrm{l}$ of $50 \%$ (v/v) $\mathrm{m}^{7}$ GTP-Sepharose $4 \mathrm{~B}$ resin was added to cell extracts containing $170 \mu \mathrm{g}$ of protein and incubated for $25 \mathrm{~min}$ at $4^{\circ} \mathrm{C}$ on an Eppendorf tube shaker. The beads and bound proteins were then isolated by centrifugation in a microcentrifuge at $4^{\circ} \mathrm{C}$ and washed three times with $200 \mu \mathrm{l}$ cell lysis buffer (without detergent). The pellets were resuspended in $40 \mu \mathrm{l} 2 \times$ SDS sample buffer, boiled and centrifuged, and gels were loaded with $20 \mu \mathrm{l}$ per lane. After electrophoresis 4E-BP1 and eIF4E were detected by immunoblotting as described above.

Acknowledgements. We are grateful to Dr Simon Morley (University of Sussex) for gifts of antibodies. This work was funded by the Cancer Prevention Research Trust, the Leukaemia Research Fund and the Association for International Cancer Research. CC was supported by the AG Leventis Foundation, Universities UK (ORS Award) and the Wellcome Trust (Value in People Award). 
1. Horton LE, Bushell M, Barth-Baus D, Tilleray VJ, Clemens MJ, Hensold J. p53 activation results in rapid dephosphorylation of the elF4E-binding protein $4 \mathrm{E}-\mathrm{BP} 1$, inhibition of ribosomal protein S6 kinase and inhibition of translation initiation. Oncogene 2002; 21: 5325-5334.

2. Constantinou C, Bushell M, Jeffrey IW, Tilleray V, West M, Frost V et al. p53-induced inhibition of protein synthesis is independent of apoptosis. Eur J Biochem 2003; 270 : 3122-3132.

3. Constantinou C, Clemens MJ. Regulation of the phosphorylation and integrity of protein synthesis initiation factor elF4GI and the translational repressor 4E-BP1 by p53. Oncogene 2005; 24: 4839-4850.

4. Ruggero D, Sonenberg N. The Akt of translational control. Oncogene 2005; 24 7426-7434.

5. Ababneh M, Gotz C, Montenarh M. Downregulation of the cdc2/cyclin B protein kinase activity by binding of p53 to p34(cdc2). Biochem Biophys Res Commun 2001; 283: 507-512.

6. Herbert TP, Tee AR, Proud CG. The extracellular signal-regulated kinase pathway regulates the phosphorylation of 4E-BP1 at multiple sites. J Biol Chem 2002; 277: 11591-11596.

7. Heesom KJ, Gampel A, Mellor H, Denton RM. Cell cycle-dependent phosphorylation of the translational repressor elF-4E binding protein-1 (4E-BP1). Curr Biol 2001; 11: 1374-1379.

8. Meyuhas $O$. Synthesis of the translational apparatus is regulated at the translational level. Eur J Biochem 2000; 267: 6321-6330.

9. Gingras AC, Raught B, Sonenberg N. Regulation of translation initiation by FRAP/mTOR Genes Dev 2001; 15: 807-826.

10. Kudchodkar SB, Yu Y, Maguire TG, Alwine JC. Human cytomegalovirus infection induces rapamycin-insensitive phosphorylation of downstream effectors of mTOR kinase. J Viro 2004; 78: 11030-11039.

11. Lin Y, Brown L, Hedley DW, Barber DL, Benchimol S. The death-promoting activity of p53 can be inhibited by distinct signaling pathways. Blood 2002; 100: 3990-4000.

12. Brown $L$, Benchimol $S$. The involvement of MAPK signaling pathways in determining the cellular response to p53 activation: cell cycle arrest or apoptosis. J Biol Chem 2006; 281 3832-3840.

13. Grolleau A, Bowman J, Pradet-Balade B, Puravs E, Hanash S, Garcia-Sanz JA et al. Global and specific translational control by rapamycin in $T$ cells uncovered by microarrays and proteomics. J Biol Chem 2002; 277: 22175-22184.

14. Kubica N, Bolster DR, Farrell PA, Kimball SR, Jefferson LS. Resistance exercise increases muscle protein synthesis and translation of eukaryotic initiation factor 2Bepsilon mRNA in a mammalian target of rapamycin-dependent manner. J Biol Chem 2005; 280: 7570-7580.

15. Byrd MP, Zamora M, Lloyd RE. Translation of eukaryotic translation initiation factor 4G (elF4GI) proceeds from multiple mRNAs containing a novel cap-dependent internal ribosome entry site (IRES) that is active during poliovirus infection. J Biol Chem 2005; 280 18610-18622.
16. Berset $\mathrm{C}$, Trachsel $\mathrm{H}$, Altmann M. The TOR (target of rapamycin) signal transduction pathway regulates the stability of translation initiation factor elF4G in the yeast Saccharomyces cerevisiae. Proc Natl Acad Sci USA 1998; 95: 4264-4269.

17. Kuruvilla FG, Shamji AF, Schreiber SL. Carbon- and nitrogen-quality signaling to translation are mediated by distinct GATA-type transcription factors. Proc Natl Acad Sci USA 2001; 98: 7283-7288

18. Wang X, Beugnet A, Murakami M, Yamanaka S, Proud CG. Distinct signaling events downstream of mTOR cooperate to mediate the effects of amino acids and insulin on initiation factor 4E-binding proteins. Mol Cell Biol 2005; 25: 2558-2572.

19. Ali SM, Sabatini DM. Structure of S6 kinase 1 determines whether raptor-mTOR or rictormTOR phosphorylates its hydrophobic motif site. J Biol Chem 2005; 280: 19445-19448.

20. Geske FJ, Lieberman R, Strange R, Gerschenson LE. Early stages of p53-induced apoptosis are reversible. Cell Death Differ 2001; 8: 182-191.

21. Christophorou MA, Martin-Zanca D, Soucek L, Lawlor ER, Brown-Swigart L, Verschuren EW et al. Temporal dissection of p53 function in vitro and in vivo. Nat Genet 2005; 37: 718-726.

22. Tilleray V, Constantinou $\mathrm{C}$, Clemens MJ. Regulation of protein synthesis by inducible wildtype p53 in human lung carcinoma cells. FEBS Lett 2006; 580: 1766-1770.

23. Mungamuri SK, Yang $X$, Thor AD, Somasundaram K. Survival signaling by Notch1: mammalian target of rapamycin (mTOR)-dependent inhibition of p53. Cancer Res 2006; 66: $4715-4724$

24. Beuvink I, Boulay A, Fumagalli S, Zilbermann F, Ruetz S, O'Reilly T et al. The mTOR inhibitor RAD001 sensitizes tumor cells to DNA-damaged induced apoptosis through inhibition of p21 translation. Cell 2005; 120: 747-759.

25. Zimmer SG, DeBenedetti A, Graff JR. Translational control of malignancy: the mRNA capbinding protein, elF-4E, as a central regulator of tumor formation, growth, invasion and metastasis. Anticancer Res 2000; 20: 1343-1351.

26. Holland EC, Sonenberg N, Pandolfi PP, Thomas G. Signaling control of mRNA translation in cancer pathogenesis. Oncogene 2004; 23: 3138-3144.

27. Bjornsti MA, Houghton PJ. Lost in translation: dysregulation of cap-dependent translation and cancer. Cancer Cell 2004; 5: 519-523.

28. Bjornsti MA, Houghton PJ. The TOR pathway: a target for cancer therapy. Nat Rev Cancer 2004; 4: 335-348.

29. Johnson P, Chung S, Benchimol S. Growth suppression of Friend virus-transformed erythroleukemia cells by p53 protein is accompanied by hemoglobin production and is sensitive to erythropoietin. Mol Cell Biol 1993; 13: 1456-1463.

30. Brunn GJ, Williams J, Sabers C, Wiederrecht G, Lawrence Jr JC, Abraham RT. Direct inhibition of the signaling functions of the mammalian target of rapamycin by the phosphoinositide 3-kinase inhibitors, wortmannin and LY294002. EMBO J 1996; 15: 5256-5267.

31. Wang $L$, Proud CG. Ras/Erk signaling is essential for activation of protein synthesis by $G q$ protein-coupled receptor agonists in adult cardiomyocytes. Circ Res 2002; 91: 821-829.

Supplementary Information accompanies the paper on the Cell Death and Differentiation website (http://www.nature.com/cdd) 